\title{
The Effect of Financial Technology, Demography, and Financial Literacy on Financial Management Behavior of Productive Age in Surabaya, Indonesia
}

\author{
Ahmad Humaidi ${ }^{1}$ Muhammad Khoirudin $^{2}$ Ainun Riska Adinda ${ }^{3}$ \& Achmad Kautsar ${ }^{4 *}$ \\ Undergraduate Students ${ }^{1-3} \&$ Lecturer $^{4}$ \\ ${ }^{1-4}$ Department of Management
}

State University of Surabaya, Surabaya, East Java

Indonesia

\begin{abstract}
This study aims to examine the effect of financial technology, demographics, and financial literacy on the financial decision making of the productive age population in Surabaya. The type of research is quantitative and conclusive in the form of causality. The data used are primary data obtained from the questionnaire. The population which is used as much as 180 respondents was selected by way of judgmental sampling. The characteristics of respondents are the productive age population in Surabaya who has income and work. Mechanical analysis of the use of researchers is an analysis of regression doubled by using SPSS software version 20. Results of the study showed that the variables demographics are proxied by type of sex, income, and age did not influence on the financial management behavior in the population age productive in Surabaya. Whereas Financial Technology and Financial Literacy have a significant positive effect on Financial Management Behavior in the productive age population in Surabaya
\end{abstract}

Key Words: Financial Technology, Demographics, Financial Literacy, Financial Management Behavior.

\section{INTRODUCTION}

As a metropolitan city, Surabaya has become a center of economic, financial and business activity in East Java and its surroundings. Most of the population is engaged in services, industry and trade. Surabaya is a trade center that is experiencing rapid development. The middle class consumers have become the belle of the emergence of a marketing revolution in Indonesia in the last five years. Along with the increasing purchasing power of middle-class consumers, it has made public products and facilities including health which used to be only able to be enjoyed by the upper class now can be bought and enjoyed by the majority.

The data shows that the population structure of Surabaya City is dominated by potential age, starting from the age of 15 - 64 years, amounting to 2,205,581 people or 71.28\% compared to school age from PAUD to junior high school, aged 5-14 years, amounting to 672,030 people or $21,72 \%$, while the elderly population, aged 65 years and over amounted to 216,636 people or $7 \%$. Population age productive working age population who are already able to produce goods and services. Productive age with an age range of 15-64 years is the age at which humans are physically and biologically mature. At this age humans are at the peak of their activity. Most of the productive age have their own income or income from activities such as work, trade, and provide service facilities. So it can be said that most of the productive age are financially established.

Financial decisions that are reflected in the Financial Management Behavior model are a widely discussed issue today. This relates to the consumption behavior of people in Indonesia, including Surabaya. They tend to think short-term and are synonymous with impulsive shopping practices so that often individuals with sufficient income still experience financial problems because of financial behavior that is less responsible. Financial Management Behavior is a person's ability to manage (planning, budgeting, checking, managing, controlling, searching and storing) daily financial funds. The emergence of Financial Management Behavior is the impact of a person's desire to meet their needs in accordance with the level of income earned.

There are several factors that can affect the Financial Management Behavior including Demographics. Ida, \& Dwinta, C. Y in their research stated that income has no influence on financial management behavior due to the difference that the income from hard work alone will be different from the income obtained from other people such as those obtained from family, especially 
parents. This is reinforced by the results of research [13] states that income has no effect on one's financial behavior due to the possibility of lack of limiting research on individuals who are married or not married later in order to get a classification of one's expenditure responsibilities based on social status will be different. However, it is different from the results of research conducted by [3] which states that one of the demographic factors, namely income, has a significant effect on individual financial behavior because the higher a person's income, it is wiser to behave towards financial use than someone who has lower income. Whatever income a person has if he is unable to manage finances properly then what happens will have personal financial problems.

The next factor that can affect financial management behavior is financial literacy. Financial literacy is the ability of individuals to know financial activities such as saving, investing, insurance. In research [18] states that financial literacy has a significant effect on financial management behavior. [20] disclose the circumstances in which individuals with the financial condition of all limited, but is able to utilize and execute understanding of financial literacy in everyday life with the good it can do the implementation of financial management in the past present and future will come so that individuals do not experience financial management problems. Therefore understanding financial literacy needs to be improved so that someone is not adversely affected by ignorance of decision making in personal financial management.

The third factor is fin ancial technology. The Indonesian Internet Service Providers Association (APJII) estimates that internet users this year will grow to 60 percent from last year's number of 143.26 million. The number of users in 2017 , up from 132.7 million users last year. As a metropolitan area, Surabaya also has a community with high internet penetration, many startups from Fintech pioneered their operations in the Surabaya area. With the advancement of Financial Technology, it is suspected that there was an influence on financial management behavior.

\section{LITERATURE REVIEW}

\subsection{Financial Management Behavior}

According to [17] revealed that personal financial management behavior can be described as a learning process in planning, taking action in accordance with planning, and making improvements to the implementation of plans that need to be addressed in individuals or families. According to [20] one of the efforts in shaping the character of financial behavior is by growing personal financial management behavior by carrying out financial planning and self control of money.

From some definitions of financial management behavior according to some expert experts above, it can be concluded that someone with good financial management behavior is more likely to be able to get used to preparing financial planning, implementing planning by controlling themselves, evaluating the initial planning actions that are not in accordance with the conditions has occurred and implemented improvements to financial problems, and always monitored the condition of financial problems improvement [5].

Financial management behavior is related to a person's financial responsibilities regarding how to manage their finances. Financial responsibility is the process of managing money and other assets in ways that are considered productive. Money management (Money Management) is the process of mastering using financial assets [10]. The development of behavior finance was pioneered by the existence of a person's behavior in the decision making process [10]. Financial behavior should lead to responsible and responsible financial behavior so that all finances, both individuals and families, can be managed properly. The emergence of financial management behavior, is the impact of the magnitude of a person's desire to meet their needs in accordance with the level of income earned. According to [7] a person's financial management behavior can be classified through 4 things: Consumption, Cash-flow Management, Saving and Investment, Credit Management.

\subsection{Financial Technology}

Financial Technology (Fintech) is the result of a combination of financial services and technology that ultimately changes the business model from conventional to moderate, which initially had to meet or meet face to face and bring some cash, now it can be done with long distance transactions by making payments that can done in seconds (www.bi.go.id). According to Bank Indonesia regulations, fintech is a technology in a financial system that produces new products, technology services and business models and can have an impact on monetary stability, financial system stability or efficiency, smoothness, security and reliability of payment systems (PBI, 2017: 3). The purpose of Financial Technology (Fintech) is that Bank Indonesia regulates the implementation of financial technology to encourage innovation in the financial sector by applying the principles of consumer protection and risk management and prudence in order to maintain monetary stability, financial system stability and payment systems that are efficient, smooth, safe and reliable (PBI, 2017: 4).

\subsection{Demography}

According to [16], the definition of income is an increase in the gross profit of the owner of capital obtained from the sale of traded goods, service activities expected by consumers, renting out assets, lending money, and all business operational activities in obtaining maximum income. Than, income has a meaning that the total amount of goods and services that can meet the standard 
of living of the community, meaning that by having income owned by each individual can be said as income per capita population, one of these per capita income functions can be a benchmark of progress or development the economy. According to [22], the definition of income is a maximum value that can be consumed by someone in a period that expects the same condition at the end as the initial state of the period.

\subsection{Financial Literacy}

Financial literacy is a set of knowledge and skills of an individual that makes it possible to make decisions effectively with all financial resources they have [2]. According to [6], namely financial literacy is the ability to make informed judgment and to take effective decisions regarding the use and management of money" which means financial literacy is the ability to make judgments: information and make effective decisions about the use and management of money. Financial literacy is knowledge, skills and beliefs that influence attitudes and behaviors to improve the quality of decision making and financial management in order to prosper. [12] Financial literacy according to the Financial Services Authority (OJK) is knowledge, skills and confidence that affect attitudes and behaviors to improve quality in decision making and financial management in order to prosper.

From the definition of financial literacy above, it can be concluded that financial literacy or better known as financial literacy is an individual's understanding of financial knowledge, how an individual's ability to analyze and apply it in everyday life and be able to make financial decisions and be aware of the risks that will faced with the decision take. According to [15] stated that the understanding of financial literacy is the ability of individuals to understand, obtain, and evaluate all information that is considered relevant in making decisions by understanding the financial risks that result. [14] revealed that to improve financial literacy in financial decision making, it starts from making careful planning and being able to manage every pattern of financial decision making behavior in life such as making a home purchase and financial planning in retirement.

According to [19] suggested that there are various important factors that can affect financial literacy, that is, from the social environment the individual is in, family learning behavior, financial education pursued, one's experience in using finance. From various definitions of financial literacy according to some expert experts in their fields above, it can be concluded that financial literacy is a study of economic science which includes how to get money, understand, evaluate all information before acting in financial decision making by means of planning and being able to manage finances well which can be influenced by the social environment, family education, other people's experiences in financial use.

\section{METHOD}

This type of research is quantitative research with causal nature. The location chosen in this study is Surabaya. The population selected in this study is the productive age population in Surabaya by $73,44 \%$ of the 2.87 million (total population in Surabay a) which is about 2.1 million people. Judgment sampling is chosen by considering the number of indicators, it is found the number of samples is 180 respondents of productive age in Surabaya. Data analysis using SPSS with multiple linear regression with the following equation:

Financial Management Behavior $=\alpha+\beta 1$ financial technology $+\beta 2$ gender $+\beta 3$ income $+\beta 4$ age $+\beta 5$ financial literacy $+\mathrm{e}$

\section{RESULT}

Table 1 shows that the corrected item total correlation results for each statement item are above the number 0.300 . Then the answers given by respondents in each item statement declared valid. Based on the table also shows the results of cronbac h's alpha of above 0.700 . Then it can be concluded that the three variables are in a reliable condition.

Table 1. Validity and Reliability Test

\begin{tabular}{|c|c|c|c|c|c|}
\hline Item & Validity Test & Reliabilitily Test & Item & Validity Test & Reliabilitily Test \\
\hline FINTECH.1 & 0.633 & \multirow{10}{*}{0,926} & FMB1 & 0.660 & \multirow{5}{*}{0,739} \\
\hline FINTECH.2 & 0.564 & & FMB 2 & 0.582 & \\
\hline FINTECH.3 & 0.746 & & FMB 3 & 0.435 & \\
\hline FINTECH.4 & 0.788 & & FMB 4 & 0.567 & \\
\hline FINTECH.5 & 0.767 & & FMB 5 & 0.275 & \\
\hline FINTECH.6 & 0.773 & & & & \\
\hline FINTECH.7 & 0.787 & & & & \\
\hline FINTECH.8 & 0.768 & & & & \\
\hline FINTECH.9 & 0.726 & & & & \\
\hline FINTECH.10 & 0.649 & & & & \\
\hline FINLIT.1 & 0.306 & \multirow{7}{*}{0,759} & & & \\
\hline FINLIT.2 & 0.536 & & & & \\
\hline FINLIT.3 & 0.571 & & & & \\
\hline FINLIT.4 & 0.388 & & & & \\
\hline FINLIT.5 & 0.538 & & & & \\
\hline FINLIT.6 & 0.210 & & & & \\
\hline FINLIT.7 & 0.412 & & & & \\
\hline
\end{tabular}


International Journal of Advances in Scientific Research and Engineering (ijasre), Vol 6 (1), January-2020

\begin{tabular}{|l|r|r|r|}
\hline FINLIT.8 & 0.529 & & \\
\hline FINLIT.9 & 0.342 & \multirow{5}{*}{} & \\
\hline FINLIT.10 & 0.439 & & \\
\hline
\end{tabular}

For multi collinearity test shows five independent variables have a VIF value less than 10 and a tolerance value greater than 0.1 so it can be concluded that there is no multi collinearity. Based on a normal probability plot graph, it appears that there are points that spread around a straight diagonal line and follow in the direction of the diagonal line, hereby showing that the data distribution is normally distributed [8]. This shows that the regression model is feasible to use to predict financial management behavior based on the independent variables of financial technology and financial literacy.

Table 2. t-test and f-test

\begin{tabular}{|l|r|r|c|}
\hline \multicolumn{1}{|c|}{ Variable } & Unstandardized Coefficients & t & sig \\
\hline (Constant) & -0.079 & -0.254 & 0.800 \\
\hline Gender & -0.030 & -0.408 & 0.684 \\
\hline Income & -0.067 & -0.968 & 0.334 \\
\hline Age & -0.005 & -0.408 & 0.684 \\
\hline Financial Technology & 0.155 & 2.579 & 0.011 \\
\hline Financial Literacy & 0.898 & 11.076 & 0.000 \\
\hline F-test & & 39.346 & 0.000 \\
\hline Adjusted R Square & 0.517 & & \\
\hline
\end{tabular}

Based on table 2 shows that the independent variables are financial technology, gender, income, age, and financial literacy obtained by the equation 1 mode of multiple linear regression, namely :

$\mathrm{Y}=-0,079+0,155$ Financial Technology $+0,898$ Financial Literacy $+\mathrm{e}$

Based on the statistical $F$ test table calculation, it can be intended that the significance value of 0,000 is less than 0.05 on the basis of decision making is to have a significance level of $5 \%$ or 0.05 . Then the regression model can be used as predicting financial management behavior, or it can be said that financial technology, demographics, financial literacy simultaneously affect the financial management behavior. The amount of the independent variables affect the dependent variable was $51,7 \%$, the remaining $48.3 \%$ influenced by other variables.

Gender with a significance value of 0.684 is greater than 0.05 and $t$ arithmetic of -0.408 , it can be concluded that gender has no effect on financial management behavior. This is supported by [1] that gender does not significantly influence student behavior in financial management. Revenue with a significance value of 0.334 is greater than 0.05 and $t$ arithmetic of -0.968 , it can be concluded that income has no effect on financial management behavior. This is consistent with findings from [21] showing that income or demographic factors do not affect a person's financial behavior or income does not become a benchmark on the behavior of individual financial management. Age with a significance value of 0.684 is greater than 0.05 and $t$ arithmetic of 0.408 , it can be concluded that age has no effect on financial management behavior. This is supported by [1] which states that age does not affect students in managing finances. So it can be concluded that demographics have no effect on financial management behavior.

Financial technology with a significance value of 0.011 less than 0.05 and $\mathrm{t}$ arithmetic of 2.579 , it can be concluded that financial technology influences financial management behavior. The value of $t$ is positive, the relationship between financial technology and financial management behavior is positive or unidirectional. This shows the important role of financial technology in financial management behavior. Financial literacy with a significance value of 0,000 is smaller than 0.05 and $t$ arithmetic of 11.706, it can be concluded that financial literacy affects the financial management behavior. The value of $t$ is positive, the relationship between financial literacy and financial management behavior is positive or unidirectional. This is supported by the study of [11], [3], [9], [18] who found that financial literacy has a relationship to financial management behavior. This is because that there are things that can affect it, namely the experience of financial expenditure, the role of the family becomes the main focus in financial education, and create awareness in the home environment about the importance of achieving financial welfare behavior in life.

\section{CONCLUSION}

The results showed that demographic variables are proxied by gender, income, and age did not affect the financial management behavior in the productive age population in Surabaya. Whereas Financial Technology and Financial Literacy have a significant positive effect on Financial Management Behavior in productive age population in Surabaya. The implication for the community with the existence of Financial Technology can make every individual use Financial Technology well in daily life. In addition, 
people need to have an understanding of Financial Literacy because each individual will gain insight into the importance of applying Financial Literacy in everyday life. The next researcher can test the research variables in the community and with a larger amount of data. With the limitations of this study, it is expected to be refined in further research.

\section{REFERENCES}

1. Achadiyah, B, N dan Laily, N., "Pengaruh Locus Of Control Terhadap hasil Belajar Mahasiswa Akuntansi", Jurnal Pendidikan Akuntansi Indonesia, Vol. XI, No. 2, 2013 pp. 11-13.

2. Adler H. Manurung dan Lutfi T. Rizky, “Succesful Financial Planner : A Complete Guide”, Jakarta : Grasindo. 2009.

3. Andrew, V., \& Linawati, N., "Hubungan Faktor Demografi dan Pengetahuan Keuangan Dengan Perilaku Keuangan Karyawan Swasta di Surabaya', Finesta, 2(2), 2014, 35-39.

4. Arofah, A.A., Purwaningsih, Y., \& Indriayu, M., "Financial Literacy, Materialism and Financial Behavior", International Journal of Multicultural and Multireligious Understanding (IJMMU), $\quad$ Vol. $5, \quad$ No. $4 . \quad 2018$ http://dx.doi.org/10.18415/ijmmu.v5i4.171

5. Asandimitra, Nadia; and Kautsar, Achmad, "The Influence Of Financial Information, Financial Self Efficacy, And Emotional Intelligence To Financial Management Behavior Of Female Lecturer”, Humanities \& Social Sciences Reviews, Vol 7, No 6, 2019, 2019, pp 1112-1124.

6. Bhushan, Puneet - Medury, Yajulu, "Financial Literacy and Its Determinants", International Journal of Engineering, Business and Enterprise Applications, Volume.4, Issue.2, 2013, pp.155-160

7. Dew, J., and Xiao, J. J.,"The Financial Management Behavior Scale Development and Validation", Journal of Financial Counseling and Planning, 22(1), 2011.

8. Ghozali, Imam, "Aplikasi Analisis Multivariate dengan Program IBM SPSS 23 (8th ed.)", Semarang: Badan Penerbit Universitas Diponegoro. 2016

9. Herawati, N. T., "Kontribusi Pembelajaran Di Perguruan Tinggi Dan Literasi Keuangan Terhadap Perilaku Keuangan Mahasiswa. Jural Pendidikan Dan Pengajaran, 1-3(48), 2015, 60-70.

10. Ida, \& Dwinta, C. Y., "Pengaruh Locus of Control, Financial Knowledge, Income Terhadap Financial Management Behavior", Jurnal Bisnis Dan Akuntansi, 12(3), 2010, 131-144.

11. Jamal, Amer. A.A. et al, "The Effects of Social Influence and Financial Literacy on Savings Behavior A Study on Students of Higher Learning Institutions in Kota Kinabalu, Sabah, International Journal of Business and Social Science, Vol. 6, No. 11(1). 2015

12. Kautsar, Achmad; and Asandimitra, Nadia, "Financial Knowledge as Youth Preneur Success Factor", Journal of Social and Development Sciences, Vol. 10, No. 2, 2019, pp. 26-32.

13. Kholilah, N. Al, \& Iramani, R. (2013). "Studi Financial Management Behavior Pada Masyarakat Surabaya", Journal of Business and Banking, 3(1), 2013, pages $69-80$.

14. Mahdzan, N. S., \& Tabiani, S. "The impact of financial literacy on individual saving: An exploratory study in the malaysian context”, Transformations in Business and Economics, 12(1), 2013, 41-55.

15. Mason, C., \& Wilson, R., “Conceptualising financial literacy”, Business School Research Series, 7(1), 2000, 1-41. Retrieved from https://dspace.lboro.ac.uk/dspace-jspui/handle/2134/2016

16. Niswonger, "Prinsip Prinsip Akuntansi. Edisi Kesembilanbelas". Jakarta: Erlangga. 2006.

17. Parrotta Jodi Lynne Mcfarlane, "The impact of financial attitude and knowledge on financial management and satisfaction", Thesis The University of British Columbia, 1992.

18. Sabri, M., \& Falahati, L., "Estimating a Model of Subjective Financial Well-Being among College Students, International Journal of Humanities and Social Science, 2(18), 2012, 191-199.

19. Shim, S., Barber, B. L., Card, N. A., Xiao, J. J., \& Serido, J., "Financial Socialization of First-year College Students: The Roles of Parents, Work, and Education", Journal of Youth and Adolescence, 39(12), 20101457-1470. https://doi.org/10.1007/s10964-009-9432-x

20. Sina, P. G., \& Noya, A. "Kecerdasan Spiritual Terhadap. Manajemen”, Jurnal Manajemen, Vol.11, No.2, 2012.

21. Wida Purwidianti \& Rina Mudjiyanti, “Analisis Pengaruh Pengalaman Keuangan dan Tingkat Pendapatan terhadap Perilaku Keuangan Keluarga di Kecamatan Purwokerto Timur", Jurnal Manajemen Dan Bisnis, Vol 1, No 2, 2016, Pp.141-148.

22. Wild, J. J, "Financial Accounting : Information For Decisions. (Y. S. Bachtiar, Ed.) (Edisi Kedua)". Jakarta: Salemba Empat. 2003

* Coresponding Author : achmadkautsar@unesa.ac.id 